\title{
Nitrogen Mineralization, Forms of Acidity and Fertility Status of a Paddy Soil as Influenced by Rice Stubble Management
}

\author{
Suravi Nandi ${ }^{1 *}$, Binoy K. Medhi ${ }^{1}$, Rajen Barua ${ }^{1}$, Mrinal Saikia ${ }^{1}$, Hemanta Saikia ${ }^{2}$, \\ Kashyap P. Bezbaruah ${ }^{3}$, Prantika Kakati ${ }^{1}$, Anupama Das ${ }^{1}$ and Nilay Borah ${ }^{4}$ \\ ${ }^{1}$ Department of Soil Science, ${ }^{2}$ College of Sericulture, ${ }^{4}$ College of Horticulture, Assam \\ Agricultural University, Jorhat 785013 Assam, India \\ ${ }^{3}$ Department of Agriculture, Nonoi, Nagaon 782001 Assam, India \\ *Corresponding author
}

\section{A B S T R A C T}

An experiment was conducted in the laboratory of department of Soil Science, Assam Agricultural University, Assam (India) during November 2018 to April 2019 to evaluate

\section{Keywords}

Rice stubble, Inorganic Nfractions,

Exchangeable cations, Acidification

\section{Article Info}

Accepted:

10 July 2020

Available Online:

10 August 2020 inorganic nitrogen fractions, forms of acidity and fertility status in a rice soil as influenced by rice stubble (RS) management practices through a fifteen weeks incubation period under constant moisture regime. Untreated and glyphosate-yogurt treated rice stubble was either incorporated or left on the surface of soil-filled $(15 \mathrm{~cm}$ depth on $5 \mathrm{~cm}$ sand at the bottom) poly vinyl chloride (PVC) pipe $(25 \mathrm{~cm}$ long and $8.44 \mathrm{~cm}$ diameter), mounted on tray maintaining a constant water depth of $5 \mathrm{~cm}$ and incubated for 105 days. Incorporation of rice stubble treated with glyphosate-yogurt mixture significantly increased $\mathrm{NH}_{4}-\mathrm{N}$ in soil compared to all other treatments, but the $\mathrm{NO}_{3}-\mathrm{N}$ in soil was affected neither by incorporation nor microbe culture spray. The variation in soil $\mathrm{pH}$ was not significant among the treatments except at 105 days after incubation. Incorporation of rice stubble, irrespective of glyphosate-yogurt treatment, significantly increased exchange acidity and total acidity in soil after 42 days of incubation. The total potential acidity in soil did not vary significantly throughout the study period. The exchangeable $\mathrm{Ca}^{2+}, \mathrm{Mg}^{2+}$ and $\mathrm{K}^{+}$in soil increased significantly due to rice stubble incorporation with or without glyphosate-yogurt treatment, but the effect was not observed for cation exchange capacity of soil. Incorporation of rice stubble significantly increased available $\mathrm{P}$ and $\mathrm{K}$ contents in soil, irrespective of glyphosate-yogurt treatment.

\section{Introduction}

The productivity of winter rice in Assam has remained static during last decade (Anonymous, 2019) contrast to increase in high yielding variety acreage and total fertilizer consumption. Application of mineral fertilizer without organic manure or recycling of crop residues strongly affects soil productivity (Singh et al., 2001). The stubble management, which is left in the field till the next crop, in rice sole crop areas of the state deserves relook mainly for two reasons. First, simple and feasible rice stubble management 
holds key to expansion of area under oilseeds and summer pulses through crop intensification and diversification. Second, the left over stubbles are subject to little or slow decomposition until the pre-monsoon rain in April-May (Borah et al., 2016b,c) and the decomposition during this period lead to substantial loss of nutrients from the soil without crop cover (Bezbaruah, 2017). The availability of winter rice stubble in Assam as per 2009 estimate was 6.29 million tones (88.9\% of total rice crop residues), with a surplus of 3.75 million tonnes (Hiloidhari and Baruah, 2011). Rice straw contains about $0.6 \% \mathrm{~N}, 0.18 \% \mathrm{P}$ and $1.38 \% \mathrm{~K}$ (Mandal et al., 2004) and for every tonne removal of rice straw about $5-8 \mathrm{~kg} / \mathrm{ha} \mathrm{N}, 1.6-2.7 \mathrm{~kg} / \mathrm{ha} \mathrm{P}_{2} \mathrm{O}_{5}$ and $14-20 \mathrm{~kg} / \mathrm{ha} \mathrm{K}_{2} \mathrm{O}$ get lost (Dobermann and Fairhust, 2002).

Incorporation of rice straw without pretreatment may adversely affect nutrient availability in soil and ultimately succeeding crop yield (Singh et al., 1996), while in situ decomposition without pre-treatment is slow due to dry spell with low temperature (Borah et al., 2016b,c). Spraying mixture of glyphosate and commercial yogurt on rice stubble in situ (Borah et al., 2016 a, c) or their incorporation into soil (Bezbaruah, 2017) had significantly enhanced reduction of biomass weight and $\mathrm{C}: \mathrm{N}$ ratio of the crop residues.

The major problem in the way of efficient utilization of cereal crop residues is microbial immobilization of nitrogen in soil (Mary et al., 1996), reduction of oxygen content and production of toxic carbon compounds in soil. Response of crop residues incorporation to soil $\mathrm{pH}$ had shown contrasting results (Naramabuye and Haynes, 2006; Rosolem, 2011), mainly due to the differences in composition and types of added residues, soil properties and location (Xu et al., $2006 \mathrm{a}, \mathrm{b}$ ). Initial soil $\mathrm{pH}$ significantly affected the incorporation of crop residues with higher C:
$\mathrm{N}$ ratio like rice and low soil $\mathrm{pH}$ inhibited the nitrification (Xiao et al., 2013). Incorporation of rice straw in situ without any treatment (Tuyen and Tan, 2001) or followed by their chopping (Bailey et al., 2013) or with phosphocompost and mineral fertilizer (Bhattacharjee et al., 2013) had been reported to increase nutrient content, cation exchange capacity (Weber et al., 2007), nitrogen availability due to acidification (Xu and Coventry, 2003) or liming effect (Conyers $e t$ al., 2011) in soils.

Carbon or nitrogen mineralized after incorporation of residues had been studied under both laboratory conditions (Vanlauwe et al., 1996; Vigil and Kissel, 1991) and in field experiments (Handayanto et al., 1994, Muller et al., 1988). However, the predictions of mineralizable nitrogen based on measurements of nitrogen mineralization under field study were significantly worse than that under laboratory condition (Ros et al., 2011). The knowledge on nitrogen mineralization with rice stubble management under controlled laboratory conditions would thus aid in formulating effective nutrient management in the succeeding crop, and efficient method for recycling of the crop residues. Accordingly, a laboratory incubation study was carried out to evaluate nitrogen mineralization, forms of soil acidity and available nutrients in soil as influenced by stubble management practices.

\section{Materials and Methods}

\section{Location, soil and climate}

The present investigation was carried out during November 2018 to April 2019 at Assam Agricultural University $\left(26^{\circ} 44^{\prime} \mathrm{N}\right.$, $94^{\circ} 10^{\prime} \mathrm{E}$ and $91 \mathrm{~m}$ above MSL), Jorhat, India. The daily temperature of Jorhat decreases from November to January and then increases from February to April with an average 
maximum temperature of $28^{\circ} \mathrm{C}$ in November to $23^{\circ} \mathrm{C}$ in January, and then $24^{\circ} \mathrm{C}$ in February to $28^{\circ} \mathrm{C}$ in April, and with an average minimum temperature of $16^{\circ} \mathrm{C}$ in November to $8^{\circ} \mathrm{C}$ in January, and thereafter $13^{\circ} \mathrm{C}$ in February to $19^{\circ} \mathrm{C}$ in April. Bulk surface (0-15 $\mathrm{cm})$ soils were collected from field after harvest of winter rice crop, air dried and ground to pass through $2 \mathrm{~mm}$ sieve and the processed soil was used for the incubation experiment. The soil for the experiment had a sandy clay loam texture with 56.1 per cent sand, 25.1 per cent clay having bulk density and particle density of 1.39 and $2.36 \mathrm{Mg} / \mathrm{m}^{3}$, respectively.

The soil had total porosity of 41.1 per cent, maximum water holding capacity of 43.1 per cent and field capacity moisture content of 21.6 per cent $(\mathrm{w} / \mathrm{w})$. The $\mathrm{pH}$ of the soil was 4.6 with exchangeable acidity, total acidity and total potential acidity fractions as 0.55 , 3.41 and $18.8 \mathrm{c} \mathrm{mol}\left(\mathrm{p}^{+}\right) / \mathrm{kg}$, respectively. The lime requirement (to raise the $\mathrm{pH}$ to 6.4) of the soil in terms of $\mathrm{CaCO}_{3}$ was $11.9 \mathrm{t} / \mathrm{ha}$. The cation exchange capacity of the soil was $5.46 \mathrm{c} \mathrm{mol}\left(\mathrm{p}^{+}\right) / \mathrm{kg}$ soil, and exchangeable $\mathrm{Al}^{3+}$ content was $0.45 \mathrm{c} \mathrm{mol}\left(\mathrm{p}^{+}\right) / \mathrm{kg}$ soil. The other exchangeable cations contents were $0.17,0.23,1.12,0.78$ and $0.11 \mathrm{c} \mathrm{mol}\left(\mathrm{p}^{+}\right) / \mathrm{kg}$ soil for $\mathrm{K}^{+}, \mathrm{NH}_{4}^{+}, \mathrm{Ca}^{2+}, \mathrm{Mg}^{2+}$ and $\mathrm{Na}^{+}$, respectively with a base saturation of 38.6 per cent.

\section{Experimental set up}

The incubation was carried out using $25 \mathrm{~cm}$ long poly vinyl chloride (PVC) hollow pipe, the bottom of which was temporarily closed by fixing a woven stainless wire cloth (diameter $\leq 0.2 \mathrm{~mm}$ ) with rubber and adhesive tape. Each PVC pipe (internal diameter 8.44 $\mathrm{cm}$ and wall thickness $0.28 \mathrm{~cm}$ ) was filled with sand up to $5 \mathrm{~cm}$ from the bottom, followed by the processed soil to a thickness of $15 \mathrm{~cm}$ maintaining the dry bulk density of the soils, estimated earlier during collection of the samples. The soil-filled PVC pipes were mounted in a one litre beaker and required mass of rice stubble was applied to each column as per the treatments and incubated for 105 days. A water level of $5 \mathrm{~cm}$ thickness was maintained inside the beaker throughout the incubation period.

\section{Treatments and experimental design}

A mixture of glyphosate $(2.05 \mathrm{~g} / \mathrm{L}$ a.i.) and edible yogurt $(5 \mathrm{~g} / \mathrm{L})$ in water was freshly prepared and used as spray solution (Borah et al., 2016 a, c). Glyphosate [N(phosphonomethyl) glycine, $\left.\mathrm{C}_{3} \mathrm{H}_{8} \mathrm{NO}_{5} \mathrm{P}\right]$ is a non-selective herbicide with a water solubility of $12 \mathrm{~g} / \mathrm{L}$ at $25{ }^{0} \mathrm{C}$. The edible yogurt was collected from the local market and used for the spray. The spray was done on 20-12-2019 using a manual operated knapsack sprayer fitted with hollow cone nozzle, with a spray volume of $550 \mathrm{~L} / \mathrm{ha}$.

After the spray the stubble was kept for one hour in the field before collection for laboratory incubation. Both the treated and untreated rice stubbles were collected from the field, immediately chopped into small pieces (2.0 to $2.5 \mathrm{~cm}$ ) and added to the soil columns as per treatments. Accurately weighed 4.0 gram of fresh biomass (with $60.4 \%$ moisture content, w/w) was added to respective soil column for treated and untreated rice stubbles.

The mass of rice stubble to each soil column was calculated on the basis of surface area of the PVC pipe and average dry weight of stubbles in the field per unit area, taking five random samples using a $1 \mathrm{~m}$ x $1 \mathrm{~m}$ quadrate. Five treatments were imposed to respective columns and comprised of $\mathrm{T}_{1}-$ without rice stubble (RS), $\mathrm{T}_{2}$ - RS untreated and retained on the surface, $T_{3}-\mathrm{RS}$ untreated and incorporated into soil, $\mathrm{T}_{4}-\mathrm{RS}$ treated (glyphosate + yogurt) and retained on the surface and $\mathrm{T}_{5}-\mathrm{RS}$ treated 
(glyphosate + yogurt) and incorporated into soil. Five sets of the columns in a completely randomized design with four replications were incubated up to 105 days of imposition of the treatments.

\section{Sampling and soil analysis}

One of the several sets maintained for the experiment was dismantled periodically for analysis of soil properties at $21,42,63,84$ and 105 days after imposition of the treatments. The various physical chemical properties of the soils were estimated following standard procedures (table 1).

\section{Ammonical nitrogen $\left(\mathrm{NH}_{4}-\mathrm{N}\right)$ and nitrate nitrogen $\left(\mathrm{NO}_{3}-\mathrm{N}\right)$}

The soil was extracted with $1 \quad \mathrm{~N} \mathrm{Na}_{2} \mathrm{SO}_{4}-$ phenylmercuric acetate and $\mathrm{NH}_{4}-\mathrm{N}$ and $\mathrm{NO}_{3}-$ $\mathrm{N}$ in the solution was estimated using a uv-vis spectrophotometer (Onken and Sunderman, 1977).

\section{Available nutrients in soil}

Available nitrogen in soil was determined by modified alkaline potassium permanganate method (Subbiah and Asija, 1956) and the available phosphorous in soil was determined by Bray and Kurtz (1945) No 1 method (Jackson, 1973). The available potassium in soil was determined by extracting the soil with neutral normal ammonium acetate and the potassium in the extract was determined using a flame photometer (Jackson 1973).

\section{Statistical analysis}

A one-way ANOVA was carried out to compare the means of the different treatments. When significant F-values were detected, the differences between individual means were tested using the least significant difference (LSD) test.

\section{Results and Discussion}

\section{Soil moisture content at different days after treatments}

The soil moisture content (w/w) at different days after incubation is shown in table 2 . The soil moisture content was unaffected by the treatments and ranged from 27.2 to 31.6 per cent, which was 63.1 to $73.3 \%$ of the water holding capacity of the soil.

\section{$\mathrm{NH}_{4}-\mathrm{N}$ and $\mathrm{NO}_{3}-\mathrm{N}$ content in soil at different days after incubation}

The highest and the lowest values of $\mathrm{NH}_{4}-\mathrm{N}$ content in soil were observed for incorporation of glyphosate-yogurt treated rice stubble and without rice stubble, respectively (table 3). The ammoniumnitrogen $\left(\mathrm{NH}_{4}-\mathrm{N}\right)$ in soil significantly increased due to incorporation of yogurt treated rice stubble compared to all other treatments. In case of untreated rice stubble, incorporation did not affect $\mathrm{NH}_{4}-\mathrm{N}$ content in soil throughout the incubation period.

The $\mathrm{NO}_{3}-\mathrm{N}$ in soil was not affected by the treatments at 21 days of incubation (table 4). Thereafter, addition of rice stubble, irrespective of glyphosate-yogurt treatment or incorporation, increased $\mathrm{NO}_{3}-\mathrm{N}$ in soil over without rice stubble. The effect of yogurt or incorporation was non-significant. However, incorporation of glyphosate-yogurt treated RS showed significant increase in $\mathrm{NO}_{3}-\mathrm{N}$ content of soil compared to untreated $\mathrm{RS}$ without incorporation.

The low $\mathrm{NH}_{4}-\mathrm{N}$ content and non-significant effect on $\mathrm{NO}_{3}-\mathrm{N}$ due to rice stubble application at early period of the incubation may be attributed to immobilization of nitrogen in soil (Mohanty et al., 2010). Further, as the N-mineralization is strongly dependent on $\mathrm{C}: \mathrm{N}$ ratio (van Asten et al., 
2005; Pandey et al., 2009) the process was enhanced during later part of the incubation upon reduction in $\mathrm{C}: \mathrm{N}$ ratio of the substrate (Borah et al., 2016a,b,c) following mineralization of organic carbon. Positive changes in the contents of $\mathrm{NH}_{4}-\mathrm{N}$ and $\mathrm{NO}_{3}-\mathrm{N}$ in soil due to rice straw addition were reported earlier (van Asten et al., 2005; Mohanty et al., 2010; Yang et al., 2018). Use of cellulose degrading microbes during organic residue decomposition was reported to facilitate $\mathrm{N}$-mineralization from the substrate (Mikola et al., 2002). Increased mineralization of nitrogen with application of ${ }^{15} \mathrm{~N}$-labelled rice straw from pot culture laboratory experiment was reported (Takahashi et al., 2003). The significantly higher $\mathrm{NH}_{4}-\mathrm{N}$ content in soil incorporated with yogurt treated rice stubble was due to faster decomposition or organic matter (van Asten et al., 2005).

The $\mathrm{NO}_{3}-\mathrm{N}$ content of soils was higher than $\mathrm{NH}_{4}-\mathrm{N}$ content up to 84 days of incubation which was reverse beyond this stage. Higher $\mathrm{NH}_{4}-\mathrm{N}$ and $\mathrm{NO}_{3}-\mathrm{N}$ contents in soil with rice straw retention than removal was reported (Yana et al., 2018). The transient organic intermediates like acetate, propionate, or butyrate undergo simultaneous oxidation and alternative redox processes like denitrification (Kusel et al., 2002). Nitrate is subjected to both assimilation and dissimilation under most oxic conditions (Tiedje, 1988). Further $\mathrm{NO}_{3}-\mathrm{N}$ leaching takes place from top soil (0$10 \mathrm{~cm}$ ) due to addition of rice straw during rice season under rice-wheat cropping system (Yang et al., 2018). The present work was carried out with $15 \mathrm{~cm}$ soil column under about $70 \%$ of the water holding capacity and might have created anoxic condition at the bottom soil layer resulting in lower $\mathrm{NO}_{3}-\mathrm{N}$ content compared to $\mathrm{NH}_{4}-\mathrm{N}$ after 84 days of incubation. A decrease in $\mathrm{NO}_{3}-\mathrm{N}$ content of soil following flooding (Knoblauch et al., 2014), and at 90 days after incubation of rice straw compost (Latifah et al., 2018) was earlier reported.

\section{Soil reaction and forms of acidity at different days after incubation}

The soil $\mathrm{pH}$ values for respective treatments at different stages of the incubation are shown in table 5 . The soil $\mathrm{pH}$ was not affected by the treatments except at 105 days after incubation, where incorporation of glyphosate-yogurt treated rice stubble significantly decreased it compared to that without rice stubble.

\section{Forms of acidity in soil at different days after incubation}

The values for exchange acidity and total acidity in soil at various stages of the incubation are presented in Fig 1 and Fig 2, respectively. The exchange acidity in soil significantly increased after 42 days and up to 105 days of incubation due to incorporation of rice stubble, both treated and untreated compared to without rice stubble or unincorporated rice stubble (Fig 1).

Similar to exchange acidity in soil, the total acidity in soil significantly increased due to incorporation of rice stubble (both treated and untreated) over without rice stubble or both treated and untreated unincorporated rice stubble (Fig 2). However, in case of unincorporated rice stubbles, glyphosateyogurt treatment increased exchange acidity in soil over untreated rice stubble after 63 days of incubation.

The total potential acidity in soil was not affected by the treatments irrespective of the stages of the incubation (table 6).

The soil $\mathrm{pH}$ was not affected by the treatments except at 105 days after incubation, where significant reduction was 
observed due to incorporation of yogurt treated rice stubble compared to soil without it. A decrease in $\mathrm{pH}$ of the medium during anaerobic fermentation of rice straw followed by increase in the later stage of the experiment was reported (Zhao et al., 2014). A decrease in soil $\mathrm{pH}$ with rice straw application was earlier observed (Ayinla et al., 2016). On the other hand, an increase in soil $\mathrm{pH}$ with production of various organic acids following a decrease in early stage of rice straw decomposition was also reported (Kumari et al., 2008). Contrary to the changes in $\mathrm{pH}$ during short-term decomposition of rice straw in soil, the $\mathrm{pH}$ had remained unchanged or slightly increased under long-term experiments (Qin et al., 2011; Saothongnoi et al., 2014). The exchange acidity and total acidity of soil increased significantly due to incorporation of rice stubble, irrespective of treatment with yogurt. Increase in exchange acidity but decrease in total potential acidity during three months submergence was reported (Savant and Kibe, 1971). The bottom layer of the soil in the present work remained near saturation throughout the incubation which might have contributed to the observed change in exchange acidity.

Table.1 Soil properties and methods followed for their determination

\begin{tabular}{|c|c|c|}
\hline Parameter & Method & Reference \\
\hline Bulk density & $\begin{array}{l}\text { gravimetric method using undisturbed } \\
\text { soil core }(5.4 \mathrm{~cm} \text { dia. and } 12 \mathrm{~cm} \text { height })\end{array}$ & Blake and Hartge, 1986 \\
\hline Particle density & pycnometer box & Baruah and Borthakur, 1997 \\
\hline $\begin{array}{l}\text { Water holding } \\
\text { capacity }\end{array}$ & Keen-Raczkowski box & Baruah and Borthakur, 1997 \\
\hline $\begin{array}{l}\text { Soil moisture } \\
\text { content }\end{array}$ & gravimetric method & Baruah and Borthakur, 1997 \\
\hline Soil pH & $\begin{array}{l}\text { soil:water }(1: 2.5) \text { suspension, glass } \\
\text { electrode } \mathrm{pH} \text { meter }\end{array}$ & Jackson, 1973 \\
\hline $\begin{array}{l}\text { Cation exchange } \\
\text { capacity }\end{array}$ & centrifuge method & Baruah and Borthakur, 1997 \\
\hline $\begin{array}{l}\text { Exchangeable } \\
\text { cations extraction }\end{array}$ & $\begin{array}{l}\text { leaching the soils with } 1 \mathrm{NCH}_{3} \mathrm{COONH}_{4} \\
\text { (pH 7.0) solution under suction }\end{array}$ & Baruah and Borthakur, 1997 \\
\hline $\mathrm{Ca}^{2+}$ and $\mathrm{Mg}^{2+}$ & Versenate titration method & Richards, 1954 \\
\hline $\mathrm{Na}^{+}$and $\mathrm{K}^{+}$ & flame photometer & Jackson, 1973 \\
\hline $\mathrm{Al}^{3+}$ extraction & $1 \mathrm{~N} \mathrm{KCl}$ solution & Hesse, 1971 \\
\hline $\mathrm{Al}^{3+}$ estimation & spectrophotometer & $\begin{array}{l}\text { Sivasubramaniam and } \\
\text { Talibudeen, } 1972\end{array}$ \\
\hline $\mathrm{NH}_{4}^{+}$ & $\begin{array}{l}1 \mathrm{~N} \mathrm{Na}_{2} \mathrm{SO}_{4} \text {-phenylmercuric acetate } \\
\text { extraction and colorimetric estimation }\end{array}$ & $\begin{array}{l}\text { Onken and Sunderman, } \\
1977\end{array}$ \\
\hline Exchange Acidity & $\begin{array}{l}1 N \mathrm{KCl} \text { solution extraction and titration } \\
\text { with } 0.1 N \mathrm{NaOH} \text { (Sokolov, 1939) }\end{array}$ & McLean, 1965 \\
\hline Total acidity & $\begin{array}{l}1 N \mathrm{CH}_{3} \mathrm{COONa} \text { extraction and titration } \\
\text { with } 0.1 \mathrm{~N} \mathrm{NaOH} \text { solution }\end{array}$ & Kappen, 1934 \\
\hline $\begin{array}{l}\text { Total potential } \\
\text { acidity }\end{array}$ & $\begin{array}{l}0.5 \mathrm{~N} \mathrm{BaCl}_{2} \text { and triethanolamine }(\mathrm{pH} 8.0- \\
\text { 8.2) extraction, titration with } 0.2 \mathrm{~N} \mathrm{HCl}\end{array}$ & Baruah and Borthakur, 1997 \\
\hline Lime requirement & buffer solution (pH 6.5) extraction & Shoemaker et al., 1961 \\
\hline
\end{tabular}


Table.2 Soil moisture (\%) content (w/w) at different days after incubation

\begin{tabular}{|c|c|c|c|c|c|}
\hline \multirow[t]{2}{*}{ Treatments } & \multicolumn{5}{|c|}{ Days after incubation } \\
\hline & 21 & 42 & 63 & 84 & 105 \\
\hline Without rice straw (RS) & 29.5 & 30.8 & 28.6 & 27.2 & 29.1 \\
\hline RS unincorporated & 27.4 & 31.6 & 28.6 & 27.2 & 29.1 \\
\hline RS incorporated & 30.2 & 28.4 & 30.1 & 28.4 & 28.8 \\
\hline RS treated, unincorporated & 30.5 & 27.8 & 28.2 & 27.6 & 27.2 \\
\hline RS-treated, incorporated & 28.6 & 30.1 & 29.6 & 30.2 & 29.5 \\
\hline $\operatorname{LSD}_{\mathrm{P}=0.05}$ & NS & NS & $\mathrm{NS}$ & $\mathrm{NS}$ & $\mathrm{NS}$ \\
\hline CV \% & 6.3 & 5.8 & 8.3 & 6.8 & 5.8 \\
\hline
\end{tabular}

Table. $3 \mathrm{NH}_{4}-\mathrm{N}$ in soil at different days after incubation

\begin{tabular}{|l|l|l|l|l|l|}
\hline \multirow{2}{*}{\multicolumn{1}{|c|}{ Treatments }} & \multicolumn{4}{|c|}{$\mathbf{N H}_{\mathbf{4}}-\mathbf{N}(\mathbf{m g} / \mathbf{k g})$} & at days after incubation \\
\cline { 2 - 6 } & $\mathbf{2 1}$ & $\mathbf{4 2}$ & $\mathbf{6 3}$ & $\mathbf{8 4}$ & $\mathbf{1 0 5}$ \\
\hline Without rice straw (RS) & 0.25 & 0.29 & 0.31 & 0.56 & 0.77 \\
\hline RS unincorporated & 0.28 & 0.32 & 0.36 & 0.87 & 0.95 \\
\hline RS incorporated & 0.28 & 0.34 & 0.39 & 0.91 & 1.10 \\
\hline RS treated, unincorporated & 0.30 & 0.36 & 0.42 & 0.82 & 1.07 \\
\hline RS-treated, incorporated & 0.36 & 0.43 & 0.54 & 1.02 & 1.25 \\
\hline LSD & 0.06 & 0.05 & 0.08 & 0.11 & 0.08 \\
\hline CV \% & 12.3 & 8.6 & 11.0 & 8.5 & 7.8 \\
\hline
\end{tabular}

Table. $4 \mathrm{NO}_{3}-\mathrm{N}$ content in soil at different days after incubation

\begin{tabular}{|l|l|l|l|l|l|}
\hline \multirow{2}{*}{\multicolumn{1}{|c|}{ Treatments }} & \multicolumn{4}{|c|}{$\mathbf{N O}_{\mathbf{3}}-\mathbf{N}(\mathbf{m g} / \mathbf{k g})$} & at days after incubation \\
\cline { 2 - 6 } & $\mathbf{2 1}$ & $\mathbf{4 2}$ & $\mathbf{6 3}$ & $\mathbf{8 4}$ & $\mathbf{1 0 5}$ \\
\hline Without rice straw (RS) & 0.45 & 0.48 & 0.46 & 0.58 & 0.54 \\
\hline RS unincorporated & 0.44 & 0.56 & 0.69 & 0.77 & 0.85 \\
\hline RS incorporated & 0.47 & 0.64 & 0.76 & 0.82 & 0.81 \\
\hline RS treated, unincorporated & 0.48 & 0.59 & 0.70 & 0.85 & 0.77 \\
\hline RS-treated, incorporated & 0.54 & 0.67 & 0.81 & 0.84 & 0.84 \\
\hline LSD & $\mathrm{NS}$ & 0.10 & 0.12 & 0.11 & 0.14 \\
\hline CV \% & 9.5 & 11.3 & 10.8 & 8.7 & 10.3 \\
\hline
\end{tabular}

Table.5 Soil pH at different days after incubation

\begin{tabular}{|l|r|c|c|c|c|}
\hline \multirow{2}{*}{\multicolumn{1}{|c|}{ Treatments }} & \multicolumn{5}{|c|}{ Soil pH at different days after incubation } \\
\cline { 2 - 6 } & 21 & 42 & 63 & 84 & 105 \\
\hline Without rice straw (RS) & 4.70 & 4.73 & 4.60 & 4.63 & 4.60 \\
\hline RS unincorporated & 4.63 & 4.68 & 4.55 & 4.53 & 4.50 \\
\hline RS incorporated & 4.68 & 4.70 & 4.50 & 4.50 & 4.40 \\
\hline RS treated, unincorporated & 4.60 & 4.58 & 4.53 & 4.43 & 4.43 \\
\hline RS-treated, incorporated & 4.63 & 4.58 & 4.50 & 4.40 & 4.38 \\
\hline LSD & $\mathrm{NS}$ & $\mathrm{NS}$ & $\mathrm{NS}$ & $\mathrm{NS}$ & 0.14 \\
\hline CV \% & 3.7 & 5.5 & 1.9 & 4.7 & 4.1 \\
\hline
\end{tabular}


Table.6 Total potential acidity in soil at different days after incubation

\begin{tabular}{|c|c|c|c|c|c|}
\hline \multirow[t]{2}{*}{ Treatments } & \multicolumn{5}{|c|}{ Days after treatment $\left[\mathrm{c} \mathrm{mol}\left(\mathbf{p}^{+}\right) / \mathrm{kg}\right]$} \\
\hline & 21 & 42 & 63 & 84 & 105 \\
\hline Without rice straw (RS) & 18.9 & 17.6 & 18.6 & 17.8 & 18.1 \\
\hline RS unincorporated & 16.8 & 17.8 & 16.9 & 18.4 & 19.5 \\
\hline RS incorporated & 17.6 & 18.2 & 18.2 & 20.1 & 18.8 \\
\hline RS treated, unincorporated & 19.2 & 19.1 & 18.6 & 19.4 & 20.3 \\
\hline RS-treated, incorporated & 17.8 & 19.5 & 19.3 & 20.0 & 20.5 \\
\hline $\mathbf{L S D}_{\mathbf{P}=0.05}$ & NS & NS & NS & NS & NS \\
\hline CV \% & 8.2 & 7.0 & 5.9 & 5.7 & 6.7 \\
\hline
\end{tabular}

Table.7 Cation exchange capacity (CEC) and exchangeable cations $\left[\mathrm{c} \mathrm{mol}\left(\mathrm{p}^{+}\right) / \mathrm{kg}\right]$ in soil

\begin{tabular}{|c|c|c|c|c|c|c|c|}
\hline \multirow[t]{2}{*}{ Treatments } & \multicolumn{7}{|c|}{ CEC and exchangeable cations at 105 days after treatment } \\
\hline & CEC & $\mathrm{Ca}^{2+}$ & $\mathrm{Mg}^{2+}$ & $\mathbf{K}^{+}$ & $\mathbf{N a}^{+}$ & $\mathrm{Al}^{3+}$ & $* \mathrm{NH}_{4}^{+}$ \\
\hline Without rice straw (RS) & 5.49 & 1.12 & 0.77 & 0.18 & 0.14 & 0.46 & 4.26 \\
\hline RS unincorporated & 5.74 & 1.11 & 0.80 & 0.18 & 0.15 & 0.48 & 5.75 \\
\hline RS incorporated & 5.94 & 1.21 & 0.87 & 0.21 & 0.16 & 0.50 & 6.11 \\
\hline RS treated, unincorporated & 5.65 & 1.15 & 0.79 & 0.19 & 0.16 & 0.45 & 5.96 \\
\hline RS-treated, incorporated & 6.23 & 1.24 & 0.88 & 0.22 & 0.15 & 0.52 & 6.37 \\
\hline $\mathrm{LSD}_{\mathrm{P}=0.05}$ & 0.45 & 0.09 & 0.07 & 0.03 & NS & $\mathrm{NS}$ & 0.64 \\
\hline CV \% & 5.8 & 4.8 & 5.5 & 8.6 & 6.6 & 5.1 & 7.4 \\
\hline
\end{tabular}

Table.8 Lime requirement (LR), WHC and available nutrients in soil at 105 days after treatment

\begin{tabular}{|c|c|c|c|c|c|}
\hline \multirow{2}{*}{ Treatments } & \multirow{2}{*}{$\begin{array}{c}\text { LR* } \\
\text { (t/ha) }\end{array}$} & \multirow{2}{*}{$\begin{array}{c}{ }^{\$} \text { WHC } \\
(\%)\end{array}$} & \multicolumn{3}{|c|}{ Available nutrients (kg/ha) } \\
\hline & & & $\mathbf{N}$ & $\mathbf{P}$ & $\mathbf{K}$ \\
\hline Without rice straw (RS) & 11.9 & 43.28 & 259.7 & 5.77 & 161.8 \\
\hline RS unincorporated & 11.7 & 41.10 & 273.3 & 5.67 & 167.6 \\
\hline RS incorporated & 11.8 & 44.90 & 266.6 & 6.24 & 174.8 \\
\hline RS treated, unincorporated & 10.9 & 42.90 & 271.0 & 5.97 & 161.3 \\
\hline RS-treated, incorporated & 12.2 & 46.43 & 278.1 & 6.38 & 182.3 \\
\hline $\mathbf{L S D}_{\mathrm{P}=0.05}$ & NS & NS & NS & 0.47 & 12.5 \\
\hline CV \% & 8.2 & 8.7 & 5.3 & 5.1 & 4.8 \\
\hline
\end{tabular}

*To raise the $\mathrm{pH}$ to $6.4,{ }^{\$} \mathrm{WHC}$ - water holding capacity 
Fig.1



Fig.2

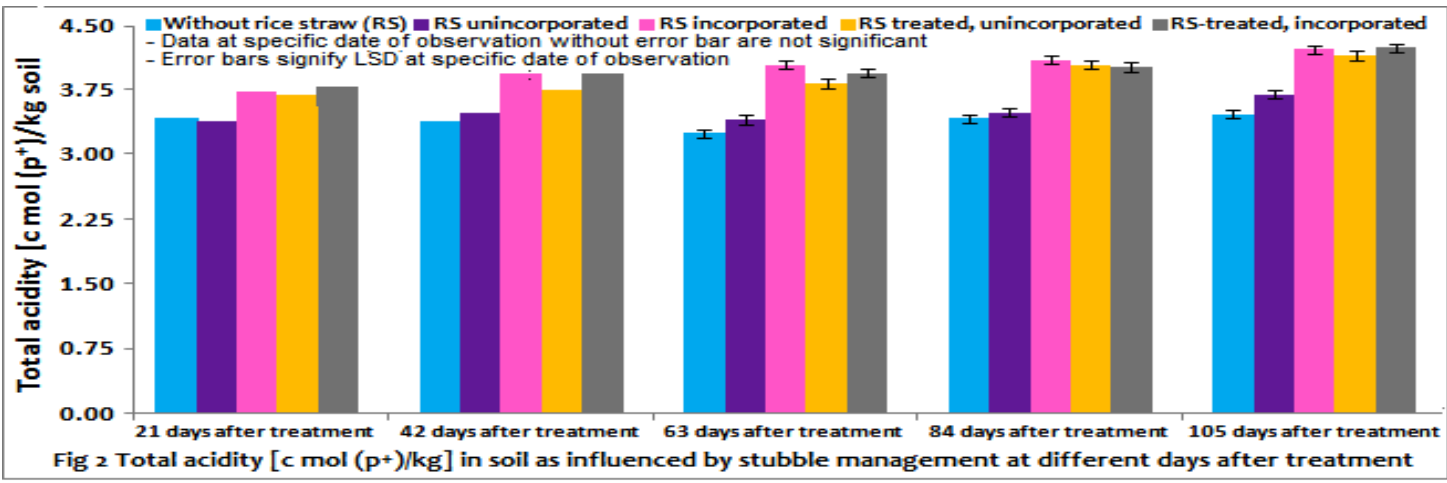

\section{Cation exchange capacity and exchangeable cations in soil}

The cation exchange capacity and exchangeable cations in soil at 105 days of incubation are presented in table 7 . The cation exchange capacity of soil significantly increased due to incorporation of rice stubble irrespective of glyphosate-yogurt treatment. The highest value was recorded for soil with rice stubble removal and the lowest for soil with incorporation of glyphosate-yogurt treated rice stubble. The effect of glyphosateyogurt treatment was statistically not significant irrespective of incorporation or leaving stubbles on the surface.

The exchangeable $\mathrm{Ca}^{2+}, \mathrm{Mg}^{2+}$ and $\mathrm{K}^{+}$in soil were significantly increased due to rice stubble incorporation with or without glyphosate-yogurt treatment (table 7). The highest values for exchangeable $\mathrm{Ca}^{2+}, \mathrm{Mg}^{2+}$ and $\mathrm{K}^{+}$were recorded for incorporation of glyphosate-yogurt treated rice stubble, while the lowest values were recorded for soil with removal of rice stubble. Similar to cation exchange capacity, the effect of glyphosateyogurt treatment was statistically not significant irrespective of incorporation or leaving stubbles on the surface for exchangeable $\mathrm{Ca}^{2+}, \mathrm{Mg}^{2+}$ and $\mathrm{K}^{+}$in soil. The exchangeable $\mathrm{NH}_{4}{ }^{+}$in soil significantly increased due to addition of rice stubble compared to their removal (table 7). The highest values for exchangeable $\mathrm{NH}_{4}{ }^{+}$were recorded for incorporation of glyphosateyogurt treated rice stubble, while the lowest values were recorded for soil with removal of rice stubble. The effect of incorporation or glyphosate-yogurt treatment was not 
statistically significant for exchangeable $\mathrm{NH}_{4}{ }^{+}$ in soil. The exchangeable $\mathrm{Na}^{+}$and $\mathrm{Al}^{3+}$ in soil were not affected by the treatments during the incubation. The highest values for exchangeable $\mathrm{Na}^{+}$and $\mathrm{Al}^{3+}$ in soil were recorded for unincorporated untreated rice stubble and incorporation of glyphosateyogurt treated rice stubble, respectively. The lowest values for exchangeable $\mathrm{Na}^{+}$and $\mathrm{Al}^{3+}$ in soil were recorded for rice stubble removal (table 7).

The cation exchange capacity (CEC), exchangeable $\mathrm{Ca}^{2+}, \mathrm{Mg}^{2+}$ and $\mathrm{K}^{+}$significantly increased due to rice stubble incorporation with or without yogurt treatment. Similar results were earlier reported for CEC (Ogbodo, 2011), $\mathrm{Ca}^{2+}$ and $\mathrm{Mg}^{2+}$ (Ogbodo, 2011; Ayinla et al., 2016) and $\mathrm{K}^{+}$(Ogbodo, 2011; Ayinla et al., 2016). The increase in CEC and exchangeable $\mathrm{Ca}^{2+}, \mathrm{Mg}^{2+}$ and $\mathrm{K}^{+}$ may be attributed to corresponding increase in organic carbon contents of the soils due to enhanced decomposition of rice stubbles followed by retention of the cations in the exchange sites. The exchangeable $\mathrm{NH}_{4}{ }^{+}$ content in soil increased significantly due to addition of rice stubbles compared to without addition, irrespective of yogurt treatment or incorporation. Exchangeable $\mathrm{NH}_{4}{ }^{+}$was the main pool of weakly fixed $\mathrm{NH}_{4}{ }^{+}$in paddy soil (Matsuoka and Moritsuka, 2011) and application of rice straw significantly increased it corresponding to an increase in exchangeable $\mathrm{NH}_{4}{ }^{+}$, indicating weakly fixed $\mathrm{NH}_{4}{ }^{+}$played as an intermediate pool between strongly fixed and exchangeable $\mathrm{NH}_{4}{ }^{+}$.

\section{Water holding capacity, lime requirement and available nutrients in soil}

The values for lime requirement (LR), water holding capacity (WHC) and available nutrients of soil at 105 days after incubation are presented in table 8 .
The lime requirement and water holding capacity of the soils were not affected by the treatments.

In case of available nutrients, the available nitrogen content of soil was not affected by the treatments (table 8). The available phosphorous and potassium in soil significantly increased due to incorporation of rice stubble, irrespective of glyphosate-yogurt treatment. The effect of adding rice stubble with or without glyphosate-yogurt treatment was statistically not significant compared to without rice stubble for both available phosphorous and potassium in soil. The organic carbon content $\left(\mathrm{K}_{2} \mathrm{Cr}_{2} \mathrm{O}_{7}\right.$ wet oxidation) of the soils (data not presented here) was not affected by the treatments up to 84 days of incubation, and increased with incorporation of glyphosate-yogurt treated rice stubble compared to without rice stubble.

The non-significant difference in water holding capacity and lime requirement, and significant increase in available phosphorous content of soils due to stubble addition are in conformity to those reported elsewhere (Zhou et al., 2002; Wei et al., 2015). The significant increase in phosphorous content of soils can be attributed to the fact that phosphorous as a constituent of crop residues was mineralized and released into the soil increasing the phosphorous content in soil. The available potassium content of soil increased due to incorporation of rice stubble with or without yogurt treatment and conform to the results reported earlier (Li et al., 2014; Zhu et al., 2019). The significant increase in potassium content in soils due to rice stubble incorporation can be attributed to enhanced decomposition of the substrate.

In conclusion the decomposition of rice stubble in paddy soil under constant moisture regime had greater effect on $\mathrm{NH}_{4}-\mathrm{N}$ than $\mathrm{NO}_{3}-\mathrm{N}$, exchange and total acidity than $\mathrm{pH}$ 
and selected exchangeable cations and available nutrients than cation exchange capacity. The changes in $\mathrm{N}$-fractions, forms of acidity, available nutrient contents and specific biological parameters in soil during and after decomposition of rice stubble need further study in response to fertilizer, organic manure, soil amendment application and crop growth.

\section{References}

Anonymous (2019). Agricultural Statistics District wise Area, Production and Average Yield of Different Crops, Directorate of Economics and Statistics, Government of Assam. https://des.assam.gov.in/informationservices/agriculture. Accessed on 24th June 2019.

Ayinla, A.A., Olayinka, B.U. and Etejere, E.O. 2016. Rice straw: a valuable organic manure for soil amendment in the cultivation of groundnut (Arachis hypogaea). Environmental and Experimental Biology, 14: 205-211.

Bailey, A., Deasy, C., Quinton, J., Silgram, M., Jackson, B. and Stevens, C. 2013. Determining the cost of in-field mitigation options to reduce sediment and phosphorus loss. Land Use Policy, 30: 234-242.

Baruah, T.C. and Barthakur, H.P. 1997. A textbook of soil analysis.Vikash Publishing, PVT Ltd., New Delhi.

Bezbaruah, K.P. 2017. Soil properties and summer moong bean yield under winter rice stubble management. M. Sc. (Agri) Thesis, Assam Agricultural University, Jorhat-785013, Assam, India.

Bhattacharjee, B., Saha, N., Debnath, A., Sen, S., Roy, S.S. and Mukherjee, D. 2013. In situ Management of Rice Stubble in Relation to Soil Nitrogen Status Vis-aVis Performance of Wheat Crop in an Entisol. American-Eurasian Journal of
Agricultural \& Environmental Sciences, 13 (7): 943-956.

Blake, G.R. and Hartge, K.H. 1986. Bulk density In: Methods of Soil Analysis. Part I-Physical and Mineralogical Methods. Second edition. Klute, A. (ed.). American Society of Agronomy, Madison WI.

Borah, N.; Barua, R., Pathak, P.K., Barua, I.C., Hazarika, K. and Phukan, A. 2016a. Rice stubble decomposition by cellulose degrading microbe and yogurt with glyphosate under rainfed upland ecosystem. International Journal of Agriculture Sciences, 8(20): 1350-1353.

Borah, N.; Barua, R., Nath, D., Hazarika, K., Phukon, A., Goswami, K. and Barua, D.C. 2016b. Low energy rice stubble management through in situ decomposition. Procedia Environmental Science, 35: 771-780.

Borah, Nilay., Pathak, P.K., Barua, R., Hazarika, K., Phukon, A. and Bezbaruah, K.P. 2016c. Stubble decomposition (in situ) of two rice varieties through microbial inoculation. In Ghosh, S.K. (ed) Utilization and Management of Bioresources. Proceedings of $6^{\text {th }}$ IconSWM 2016, Pages 65-76.

Bray, R.H. and Kurtz, L.T. 1945. Determination of total organic and available forms of phosphorous in soils. Soil Science, 59: 39-45.

Conyers, M.K., Tang, C., Poile, G.J., Liu, D.L., Chen, D., Nuruzzaman, M. 2011. A combination of biological activity and the nitrate form of nitrogen can be used to ameliorate sub surface soil acidity under dryland wheat farming. Plant and Soil, 348: 155-166.

Doberman, A. and Fairhurst, T.H. 2002. Rice straw management. Better crops international. 16 (Special supplement), pp. 7-11.

Handayanto, E., Cadish, G. and Giller, K.E. 1994. Nitrogen release from prunings of legume hedgerow trees in relation to 
quality of the prunings and incubation method. Plant and Soil, 160: 237-248.

Hesse, P.R. 1971. A textbook of soil chemical analysis. John Murray Publishers Ltd. London.

Hiloidhari, M. and Baruah, D.C. 2011. Crop residue biomass for decentralized electrical power generation in rural areas (part 1): Investigation of spatial availability. Renewable and Sustainable Energy Review, 15: 1885-1892.

Jackson, M.L. 1973. Soil Chemical Analysis. Prentice Hall of India Pvt. Ltd., New Delhi, India.

Kappen, G. 1934. Pochvennaya Kislotnost, Selkhogiz, Moscow, (cf. J. Indian Soc. Soil Sci. 39: 246, 1991).

Knoblauch, R., Ernani, P.R., Deschamps, F.C., Gatiboni, L.C., Walker, T.W., Lourenço, K.S., Martins, A.A. and Pegoraro, A. 2014. Rice straw incorporated just before soil flooding increases acetic acid formation and decreases available nitrogen. Revista Brasileira de Ciencia do Solo, 38: 17784.

Kumari, A., Kapoor, K.K., Kundu, B.S. and Mehta, R.K. 2008. Identification of organic acids produced during rice straw decomposition and their role in rock phosphate. Plant and Soil Environment, 54: $72-77$.

Kusel, K., Roth, U. and Drake, H. L. 2002. Microbial reduction of $\mathrm{Fe}(\mathrm{III})$ in the presence of oxygen under low $\mathrm{pH}$ conditions. Environmental Microbiology, 4: 414-421.

Latifah, O., Ahmeda, O.H. and Majid, N.M.A. 2018. Soil pH buffering capacity and nitrogen availability following compost application in a tropical acid soil. Compost Science and Utilization, 26: 1-15.

Li, J., Lu, J., Li, X., Ren, T., Cong, R. and Zhou, L. 2014. Dynamics of potassium release and adsorption on rice straw residue. PLOS ONE, 9: 904-940.

Mandal, K.G., Mishra, A.K.; Hati, K.M., Bandyopadhyay, K.K., Ghosh, P.K. and Mohanty, M. 2004. Rice residue management options and effects on soil properties and crop productivity. Food Agriculture and Environment, 2 (1): 224231.

Mary, B., Recous, S., Darwis, D. and Robin, D. 1996. Interactions between decomposition of plant residues and nitrogen cycling in soil. Plant Soil. 181: 71-82.

Matsuoka, K. and Moritsuka, N. 2011. Dynamics of clay-fixed ammonium as a sink or source of exchangeable ammonium in a paddy soil. Soil Science and Plant Nutrition, 57: 751-758.

McLean, E.O. 1965. In Methods of Soils Analysis, Part II, (C.A. Black, Ed.), American Society of Agronomy Inc. Madison, Wisconsin, USA.

Mikola, J., Bardgett, R.D. and Hedlund, K. 2002. Biodiversity, ecosystem functioning and soil decomposer food webs. In M. Loreau, S. Naeem and P. Inchausti (eds), Biodiversity and Ecosystem Functioning: synthesis and perspectives. Oxford University Press. pp. 169-180.

Mohanty, M., Probert, M.E., Reddy, K.S., Dalal, R.C., Rao, A.S. and Menzies, N.W. 2010. Modelling N mineralization from high $\mathrm{C}: \mathrm{N}$ rice and wheat crop residues. $19^{\text {th }}$ World Congress of Soil Science, Soil Solutions for a Changing World, 1-6 August 2010, Brisbane, Australia.

Muller, M.M., Sundman, V., Soininvaara, O. and Merilainen, A. 1988. Effect of chemical composition on the release of nitrogen from agricultural plant materials decomposing in soil under field conditions. Biology and Fertility of Soils, 6: 78-83.

Naramabuye, F.X. and Haynes, R.J. 2006. 
Effect of organic amendments on soil $\mathrm{pH}$ and Al solubility and use of laboratory indices to predict their liming effect. Soil Science, 171: 754-763.

Ogbodo, E.N. 2011. Effect of crop residue on soil chemical properties and rice yield on an Ultisol at Abakaliki, Southeastern Nigeria. World Journal of Agricultural Sciences, 7: 13-18.

Onken, A.B. and Sunderman, H.D. 1977. Colorimetric determination of exchangeable ammonium, urea, nitrate and nitrite in a single soil extract. Agronomy Journal, 69: 49-58.

Pandey, A.K., Gaind, S., Ali, A. and Nain, L. 2009. Effect of bioaugmentation and nitrogen supplementation on composting of paddy straw. Biodegradation, 20: 293306.

Qin, R., Chen, F. and Gao, J. 2011. LongTerm Application of chemical fertilizers and rice straw on soil aluminum toxicity. Communications in Soil Science and Plant Analysis, 42: 66-74.

Richards, L.A. 1954. Diagnosis and improvement of saline-alkali soils. Agricultural Handbook, USDA, pp. 60.

Ros, G.H., Temminghoff, E.J.M. and Hoffland, E. 2011. Nitrogen mineralization: a review and metaanalysis of the predictive value of soil tests. European Journal of Soil Science, 62: 162-173.

Rosolem, C.A., 2011. Exchangeable basic cations and nitrogen distribution in soil as affected by crop residues and nitrogen. Brazilian Archives of Biology and Technology, 54: 441-450.

Saothongnoi, V., Amkha, S., Inubushi, K. and Smakgahn, K. 2014. Effect of rice straw incorporation on soil properties and rice yield, Thai Journal of Agricultural Science, 47: 7-12.

Savant, M.K. and Kibe, M.M. 1971. Influence of continuous submergence on $\mathrm{pH}$, exchange acidity and $\mathrm{pH}$-dependent acidity in rice soils. Plant and Soil, 25: 205-208.

Shoemaker, H. E., McLean, E. O. and Pratt, P.F. 1961. Buffer methods for determining lime- requirement of soils with appreciable amounts of extractable aluminium. Proceedings of the Soil Science Society of America, 25: 274-277.

Singh, B.; Bronson, K. F.; Singh, Y.; Khera, T. S. and Pasuquin, E. (2001). Nitrogen15 balance as affected by rice residue management in a rice-wheat rotation in northwest India. Nut. Cycl. Agroeco. 59: 227-237.

Sivasubramaniam, S. and Talibudeen, O. 1972. Potassium-aluminium exchange in acid soil. 1. Kinetics. Journal of Soil Science, 23: 163-176.

Sokolov, A. V. 1939. Kimizastia sots Zemledelia, 7, (c.f. J. Indian Soc. Soil Sci. 246, 1991).

Subbiah, K. and Asija, G.L. 1956. A rapid procedure for determination of available nitrogen in soils. Current Science, 25: 259-260.

Takahashi, S., Uenosono, S. and Ono, S. 2003. Short- and long-term effects of rice straw application on nitrogen uptake by crops and nitrogen mineralization under flooded and upland conditions. Plant and Soil, 251:291-301.

Tiedje, J.M. 1988. Ecology of denitrification and dissimlatory nitrate reduction to ammonium. In A. J. Zehnder and W. Stumm (eds.), Biology of Anaerobic Microorganisms. Wiley, New York. pp. 179-243.

Tuyen, T.Q. and Tan, P.S. 2001. Effects of straw management, tillage practices on soil fertility and grain yield of rice. Omonrice, 9: 74-78.

Vanlauwe, B., Nwoke, O.C., Sanginga, N. and Merckx, R. 1996. Impact of residue quality on the $\mathrm{C}$ and $\mathrm{N}$ mineralization of leaf and root residues of three agroforestry species. Plant and Soil, 183: 
221-231.

Van Asten, P.J.A., van Bodegom, P.M., Mulder, L.M. and Kropff, M.J. 2005. Effect of straw application on rice yields and nutrient availability on an alkaline and a pH-neutral soil in a Sahelian irrigation scheme. Nutrient Cycling in Agroecosystems, 72: 255-266.

Weber, J., Karczewska, A., Drozd, J., Licznar, M., Licznar, S., Jamroz, E. and Kocowicz, A. 2007. Agricultural and ecological aspects of a sandy soil as affected by the application of municipal solid waste composts. Soil Biology and Biochemistry, 39: 1294-1302.

Wei, T., Zhang, P., Wang, K., Ding, R., Yang, B., Nie, J., Jia, Z. and Han, Q. 2015. Effects of wheat straw incorporation on the availability of soil nutrients and enzyme activities in semiarid areas. PLoS One, 10(4).

Xiao, X.; Cheng, Z., Meng, H., Liu, L., Li, H. and Dong, Y. 2013 Intercropping of green garlic (Allium sativum L.) induces nutrient concentration changes in the soil and plants in continuously cropped cucumber (Cucumis sativus L.) in a plastic tunnel. PLOS ONE. 8(4): 62-173. https://doi.org/10.1371/journal.pone.0062 173.

$\mathrm{Xu}, \mathrm{R} . K$. and Coventry, D.R. 2003. Soil pH changes associated with lupin and wheat plant materials incorporated in a redbrown soil. Plant and Soil, 250: 113-119.

$\mathrm{Xu}$, J.M., Tang, C. and Chen, Z.L. 2006a. Chemical composition controls residue decomposition in soils differing in initial
pH. Soil Biology and Biochemistry, 38: 544-552.

Xu, J.M., Tang, C. and Chen, Z.L. 2006b. The role of plant residues in $\mathrm{pH}$ change of a acid soils differing in initial $\mathrm{pH}$. Soil Biology and Biochemistry, 38: 709-719.

Yana, C., Dua, T., Yana, S., Donga, S., Gonga, Z. and Zhang, Z. 2018. Changes in the inorganic nitrogen content of the soil solution with rice straw retention in northeast China. Desalinization and Water Treatment, 110: 337-348.

Yang, S., Wang, Y., Liu, R., Xing, L. and Yang, Z. 2018. Improved crop yield and reduced nitrate nitrogen leaching with straw return in a rice-wheat rotation of Ningxia irrigation district. Scientific Reports, 8: 9458. DOI:10.1038/s41598018-27776-5.

Zhao, H., Yu, H., Yuan, X., Piao, R., Li, H., Wang, X. and Cui, Z. 2014. Degradation of lignocelluloses in rice straw by BMC9, a composite microbial system. Journal of Microbiology and Biotechnology, 24: 585-591.

Zhou, J., Xu, D. and Xue, C. 2002. Study of comprehensive utilization efficiency of returning rice straw to field. Chinese Agricultural Science Bulletin, 4: 3-13.

Zhu, D., Zhang, J., Wang, Z., Muhammad, R.K., Lu, J. and Li, X. 2019. Soil available potassium affected by rice straw incorporation and potassium fertilizer application under a rice-oilseed rape rotation system. Soil Use and Management, https://doi.org/10.1111/sum.12507.

\section{How to cite this article:}

Suravi Nandi, Binoy K. Medhi, Rajen Barua, Mrinal Saikia, Hemanta Saikia, Kashyap P. Bezbaruah, Prantika Kakati, Anupama Das and Nilay Borah. 2020. Nitrogen Mineralization, Forms of Acidity and Fertility Status of a Paddy Soil as Influenced by Rice Stubble Management. Int.J.Curr.Microbiol.App.Sci. 9(08): 720-733. doi: https://doi.org/10.20546/ijcmas.2020.908.078 